\title{
A Novel Synthesis of 4-Acetoxyl 5(4H)-Oxazolones by Direct $\alpha$-Oxidation of $N$-Benzoyl Amino-Acid Using Hypervalent Iodine
}

\author{
Gang Wen, Wen-Xuan Zhang * (D) and Song Wu * \\ State Key Laboratory of Bioactive Substance and Function of Natural Medicines, Institute of Materia Medica, \\ Chinese Academy of Medical Sciences and Peking Union Medical College, Beijing 100050, China; \\ wengang@imm.ac.cn \\ * Correspondences: wxzhang@imm.ac.cn (W.-X.Z); ws@imm.ac.cn (S.W.); Tel.: +86-010-8316-3542 (S.W.)
}

Received: 17 June 2017; Accepted: 29 June 2017; Published: 3 July 2017

\begin{abstract}
We have developed a new method to prepare 4-acetoxy substituted 5(4H)-oxazolones by direct oxidation of $N$-benzoyl amino-acids using hypervalent iodine. The method is efficient, economical and easy to perform for the synthesis of quaternary substituted amino acid derivatives. We used online FTIR monitoring techniques to analyze the reaction, and gave a plausible reaction mechanism.
\end{abstract}

Keywords: oxidation; hypervalent iodine; 4-acetoxyl 5(4H)-oxazolones; N-benzoyl amino-acid; online FTIR

\section{Introduction}

2-Substituted amino acids and their derivatives are known as structural elements with important physiology [1-3]. As an important synthetic intermediate of 2-substituted amino acids, 2-acetoxy-2-amino acids have attracted tremendous interest in organic synthesis [4]. However, to date, chemists have only reported a few methods to synthesize these amino acids, such as oxidating the protected cystinylserine with $\mathrm{Pb}(\mathrm{OAc})_{4}$ to the 2-acetoxy compound [5-7], using 2-benzamidotrifluorolactic acid as starting materials to yield 4-acetoxy-4-trifluoromethyl-2-phenyloxazol-5(4H)-one [8], treating oxazolone with mercuric acetate to form the diacetyl compound [9], transforming 2-acylaminoacrylate with $\mathrm{N}$-chlorosuccinimide $/ \mathrm{HCl} / \mathrm{LiOAc}$ in acetic acid to the 2-acetoxy-2-amine acid derivatives [2], converting $\beta$-lactams with ruthenium trichloride in the presence of acetaldehyde and acetic acid with molecular oxygen into the corresponding 4-acyloxy $\beta$-lactams [10], and using anodic oxidation of 2-ethoxycarbonyl-2-acetamidoacetic acid derivatives, followed by saponification of the one ester groups to 2-alkoxy-2-amino acids and 2-acetoxy-2-amino acids [11]. There are some problems in these methods: 1 . It is difficult to prepare the raw materials; 2 . The use of metal reagents is expensive and not environmentally-friendly.

Metal-free reagents such as hypervalent iodine compounds have received much attention for low toxicity, mild reaction condition, easy handling and special reactivity compared with heavy metal reagents in organic synthesis reactions. Furthermore, hypervalent iodine reagents have been widely used in various oxidations, such as oxidative dearomatized reactions [12,13], oxidative coupling reactions [14,15], oxidative halogenation reactions [16-18], oxidative cyclization reactions [19], oxidative addition [20,21], oxidative amination reaction [22], and so on.

Boto synthesized 2-acetoxy glycine through an unstable $\alpha$-iodoglycine intermediate, which was then substituted by acetate ions from the reagent $\mathrm{PhI}(\mathrm{OAc})_{2}$ (Scheme 1a) [23]. Recently, Xu's group developed a cobalt-catalyzed decarboxylative $\mathrm{C}-\mathrm{O}$ bond-forming reaction using hypervalent iodine as oxidizing agent (Scheme 1a). However, these methods involve deiodination or decarboxylative 
process, which can only give tertiary substituted carbon atoms. Herein, we wish to report a direct oxidation of $\alpha-\mathrm{C}-\mathrm{H}$ bond of $N$-benzoyl amino-acid using hypervalent iodine (Scheme $1 \mathrm{~b}$ ). With this method, a new synthesis of 4-acetoxy substituted 5(4H)-oxazolones was carried out. There are three advantages in our method: 1 . Only hypervalent iodine oxidizing agent was used, which was cheap and easy to get; 2 . Our method can directly oxidize the $\alpha-\mathrm{C}-\mathrm{H}$ bond of amino acid derivatives, which does not involve deiodination or decarboxylative process; 3 . With this method, quaternary substituted amino acid derivatives could be prepared.

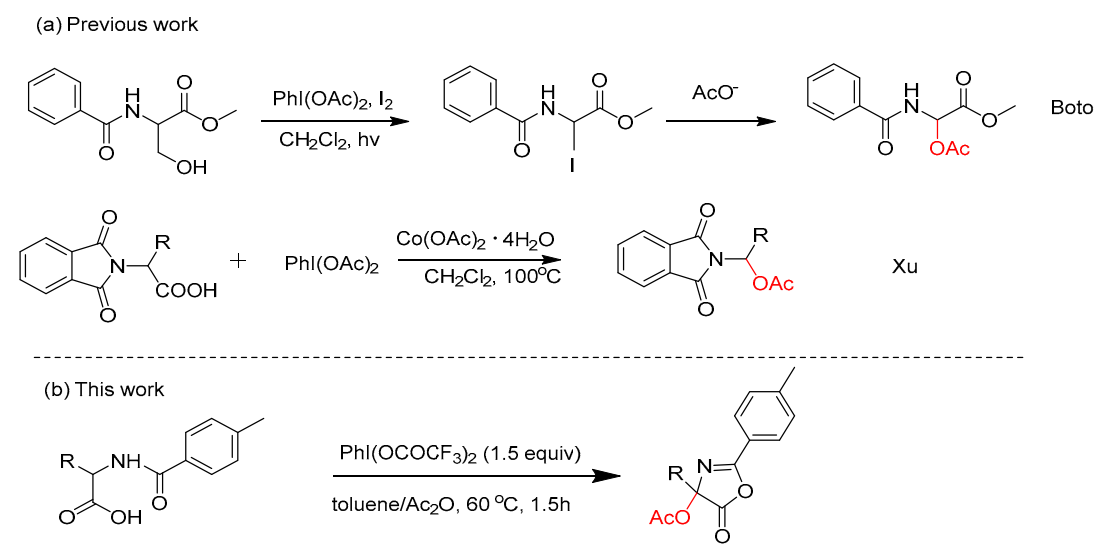

Scheme 1. Hypervalent iodine-mediated oxidation of 2-amino acids.

\section{Results}

Reaction of $\mathrm{N}$-benzoyl isoleucine (1a) with 1.0 equiv $\mathrm{PhI}\left(\mathrm{OCOCF}_{3}\right)_{2}$ in acetic anhydride and toluene $(v / v=4: 1)$ at $60{ }^{\circ} \mathrm{C}$ for $1.5 \mathrm{~h}$ gave 4 -acetoxy substituted $5(4 \mathrm{H})$-oxazolone $(\mathbf{1 b})$ as oxidative product in $40 \%$ yield $(\mathrm{dr}=1: 1$, Table 1$)$. We found that 1.5 equiv of $\mathrm{PhI}\left(\mathrm{OCOCF}_{3}\right)_{2}$ give much better yield, but the increase of $\mathrm{PhI}\left(\mathrm{OCOCF}_{3}\right)_{2}$ to 3.0 equivalent afford lower yield (entry 2-3). Replacement of $\mathrm{PhI}\left(\mathrm{OCOCF}_{3}\right)_{2}$ with $\mathrm{PhI}(\mathrm{OAc})_{2}$ or $\mathrm{PhI}(\mathrm{OPiv})_{2}$ led to the reducing of the yield, and the latter gave only $19 \%$ yield (entry 5-6). In the absence of $\mathrm{PhI}\left(\mathrm{OCOCF}_{3}\right)_{2}$, only oxazolones (1c) was afforded, which can give desired product $\mathbf{1 b}$ by the oxidative annulation with addition of $\mathrm{PhI}\left(\mathrm{OCOCF}_{3}\right)_{2}$ (see supporting Information). $\mathrm{AgF}_{2}$ gave only coupling product without desired product. The temperature also has great influence on this oxidation reaction, which gave lower yields at $30^{\circ} \mathrm{C}$ and $90{ }^{\circ} \mathrm{C}$ (entry $7-8$ ). Further assessment of the solvent effect indicated that toluene was the best solvent for this reaction, providing higher yield than other commonly used solvents such as ACN, DCE, Acetone and THF (entry 10-13).

Table 1. Direct $\alpha$-oxidation of $N$-benzoyl amino-acid using hypervalent iodine.

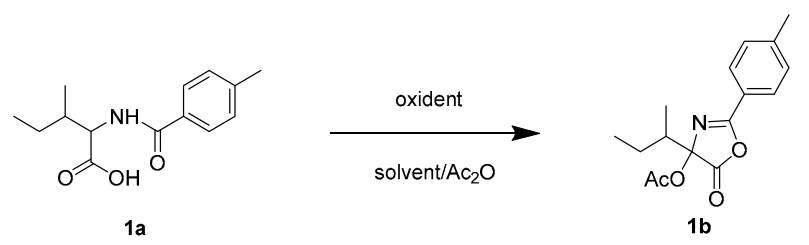

\begin{tabular}{ccccc}
\hline Entry & Oxidant (equiv) & Temp $\left({ }^{\circ} \mathbf{C}\right)$ & Solvent & Yield (\%) ${ }^{\mathbf{a}}$ \\
\hline 1 & $\mathrm{PhI}_{\left(\mathrm{OCOCF}_{3}\right)_{2}(1)}$ & 60 & toluene & 40 \\
2 & $\mathrm{PhI}_{\left(\mathrm{OCOCF}_{3}\right)_{2}(1.5)}$ & 60 & toluene & $68\left(63^{\mathrm{b}}\right)$ \\
3 & $\mathrm{PhI}\left(\mathrm{OCOCF}_{3}\right)_{2}(3)$ & 60 & toluene & 50 \\
4 & $\mathrm{PhI}\left(\mathrm{OCOCF}_{3}\right)_{2}(0)$ & 60 & toluene & no \\
5 & $\mathrm{PhI}(\mathrm{OAc})_{2}(1.5)$ & 60 & toluene & 42 \\
6 & $\mathrm{PhI}\left(\mathrm{OPiv}_{2}(1.5)\right.$ & 60 & toluene & 19 \\
7 & $\mathrm{AgF}_{2}(1.5)$ & 60 & toluene & no \\
\hline
\end{tabular}


Table 1. Cont

\begin{tabular}{ccccc}
\hline Entry & Oxidant (equiv) & Temp $\left({ }^{\circ} \mathbf{C}\right)$ & Solvent & Yield (\%) $^{\text {a }}$ \\
\hline 8 & $\mathrm{PhI}_{\left(\mathrm{OCOCF}_{3}\right)_{2}(1.5)}$ & 30 & toluene & 38 \\
9 & $\mathrm{PhI}_{\left(\mathrm{OCOCF}_{3}\right)_{2}(1.5)}$ & 90 & toluene & 43 \\
10 & $\mathrm{PhI}_{\left(\mathrm{OCOCF}_{3}\right)_{2}(1.5)}$ & 60 & ACN & 50 \\
11 & $\mathrm{PhI}\left(\mathrm{OCOCF}_{3}\right)_{2}(1.5)$ & 60 & DCE & 43 \\
12 & $\mathrm{PhI}_{\left(\mathrm{OCOCF}_{3}\right)_{2}(1.5)}$ & 60 & Acetone & 8 \\
13 & $\mathrm{PhI}_{\left(\mathrm{OCOCF}_{3}\right)_{2}(1.5)}$ & 60 & THF & no
\end{tabular}

a Yields were based on 1H NMR analysis of reaction mixture after $1.5 \mathrm{~h}$ using (2E)-2-Butenedioic acid as standard;

${ }^{b}$ Isolated yields.

With the optional conditions in hand, we then examined the substrate scope of $\mathrm{N}$-benzoyl amino acid substrates (Table 2). Both $\alpha$-alkyl and benzyl substituted $N$-benzoyl amino-acid (2a-10a) gave desired 4-acetoxyl 5(4H)-oxazolones (2b-10b) in moderated yields with some coupling products in $0-20 \%$ yields (except for $1 \mathbf{a}$, see supporting information). Beside coupling products, $\alpha$-alkyl substrates $3 \mathbf{a}$ and $5 \mathbf{a}$ also gave rearrangement product $N$-(1-oxo-alkyl)-benzamide in about $20 \%$ yields, while substituted $N$-benzoyl amino-acids (6a-10a) gave some elimination products in about $10-30 \%$ yields (see supporting Information). In these conditions, ether and ester groups were very tolerant, as shown in entry 8-9.

Table 2. Substrate scope of N-benzoyl amino-acids.

Entry Substrates Products (Isolated Yield) Entry

\section{Discussion}

In order to study the reaction kinetics, we used online FTIR techniques (fourier-transform infrared spectra, React IR 15) to monitor the reaction [24-26]. At first, we collected the FTIR data of raw material $\mathbf{1 a}$, the intermediate $\mathbf{1 c}, \mathrm{PhI}\left(\mathrm{OCOCF}_{3}\right)_{2}$, acetic acid, trifluoroacetic acid and product $\mathbf{1 b}$ 
in the solvent (anhydrous toluene:acetic anhydride $=4: 1$ ) respectively. To prove the formation of intermediate $1 \mathrm{c}$ before the oxidative annulation, we added the $\mathrm{PhI}(\mathrm{OCOCF})_{2}$ in the reaction system 10 min after raw material 1a and acetic anhydride were heated at $60{ }^{\circ} \mathrm{C}$. In the experiments, ReactIR was continuously used to acquire online IR spectra. The ConcIRT analysis and 3D surface plot tracked changes in absorbance profiles that occur over time of the intermediate 1c, $\mathrm{PhI}\left(\mathrm{OCOCF}_{3}\right)_{2}$, acetic acid, trifluoroacetic acid, and product 1b, which were shown in Figures 1 and 2.

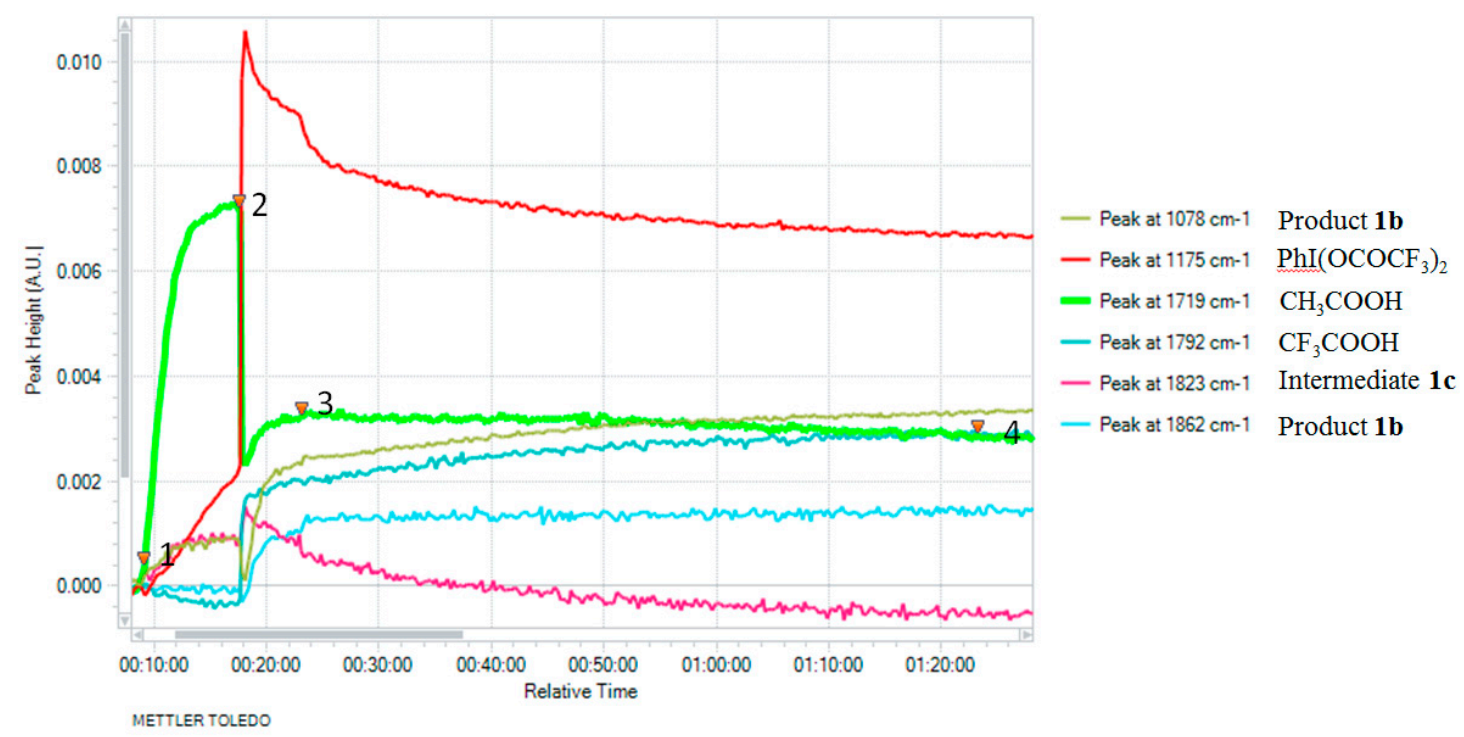

Figure 1. ConcIRT component profiles of oxidative reaction. 1. Added the material; 2. Added the oxidation $\mathrm{PhI}\left(\mathrm{OCOCF}_{3}\right)_{2} ; 3,4$. Got sample.

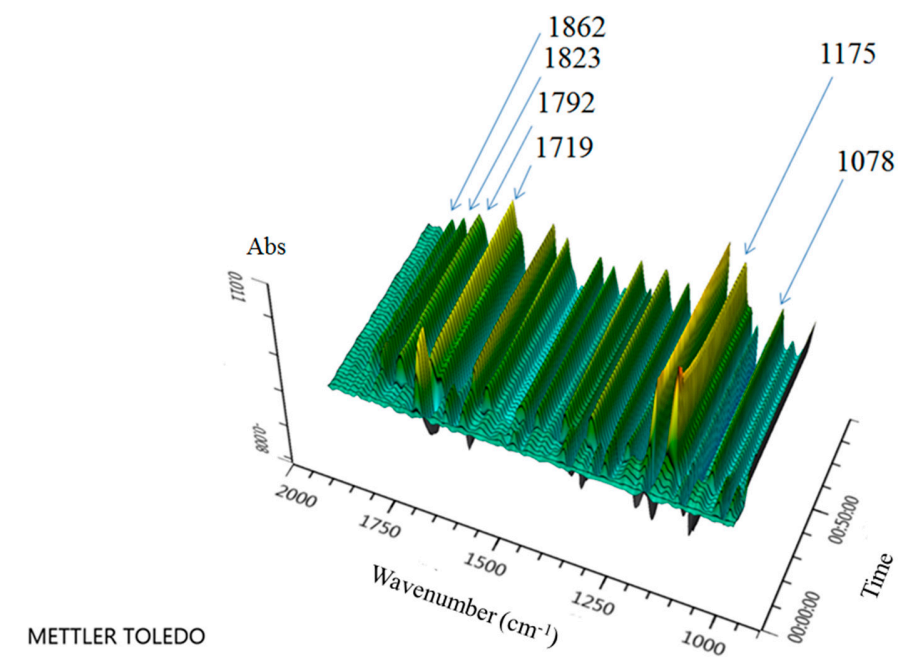

Figure 2. In situ reaction of IR, 3D surface plot of oxidative reaction.

At first, the peak height at $1822 \mathrm{~cm}^{-1}(\mathrm{C}=\mathrm{O}$ bond, pale red line) increased due to the producing of the intermediate $1 c$, and it decreased when we add the oxidant $\mathrm{PhI}(\mathrm{OCOCF})_{2}$ to the reaction system. The peak at $1719 \mathrm{~cm}^{-1}(\mathrm{C}=\mathrm{O}$ bond, green line) increased due to the formation of acetic acid, and it reduced because of the ligand exchange with $\mathrm{PhI}\left(\mathrm{OCOCF}_{3}\right)_{2}$. The peak at $1792 \mathrm{~cm}^{-1}(\mathrm{C}=\mathrm{O}$ bond, wathet blue line) increased, showing the formation of trifluoroacetic acid. At the same time, the peak at $1078 \mathrm{~cm}^{-1}$ (C-O bond, brown line) and $1862 \mathrm{~cm}^{-1}(\mathrm{C}=\mathrm{O}$ bond) began to increase, indicating the formation of the product $\mathbf{1 b}$. Moreover, the variation trend of ConcIRT showed that the complete reaction needed about $1.5 \mathrm{~h}$ (As shown in the Figure 1). 
On the basis of the above experiments, a plausible reaction mechanism was proposed as shown in Scheme 2 [27]. At first, the raw material 1a was converted to intermediate 1c [28], which was then transformed to the enoliazted intermediate 1d. After the ligand exchange of $\mathrm{PhI}\left(\mathrm{OCOCF}_{3}\right)_{2} \mathrm{with}$ $\mathrm{AcOH}$, the I-O bond of 1 e was formed accompanied by the leave of $\mathrm{CF}_{3} \mathrm{COOH}$. Then the $\mathrm{AcO}^{-}$added to the double bond accompanied by the elimination of $\mathrm{PhI}$, the final product $\mathbf{1 b}$ was afforded.
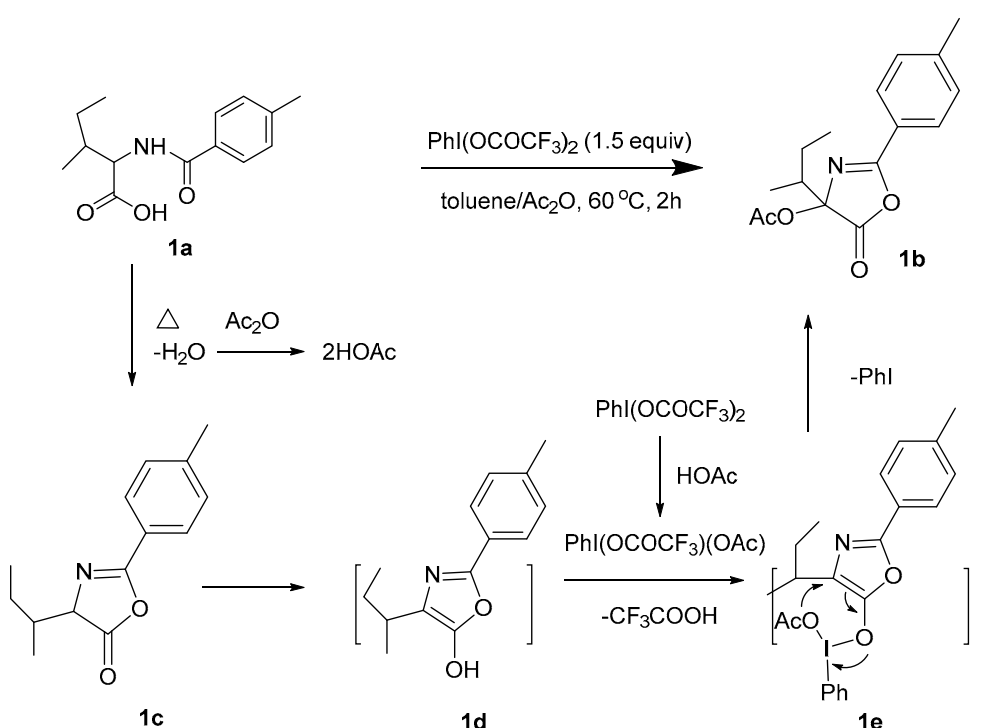

Scheme 2. A plausible reaction mechanism of the oxidative annulation reaction.

\section{Conclusions}

In summary, we have developed a new method to prepare 4-acetoxy substituted 5(4H)-oxazolones by direct oxidation of $N$-benzoyl amino-acids using hypervalent iodine. These 4-acetoxy substituted $5(4 H)$-oxazolones can be used as synthetic intermediates for different bioactive compounds or peptidomimetic constituents. The method is efficient, economical and easy to perform for the synthesis of quaternary substituted amino acid derivatives. We used online FTIR monitoring techniques (React IR 15) to monitor the reaction, and gave a plausible reaction mechanism. The synthetic applications of this process are currently underway in our laboratory.

Supplementary Materials: Supplementary materials are available online.

Acknowledgments: We thank The National Natural Science Fund (81602958), Beijing Natural Science Foundation (7164282) and the Fundamental Research Funds for the Central Universities (2016ZX350006) for financial support.

Author Contributions: W.-X.Z. and S.W. conceived and designed the experiments; G.W. performed the experiments; W.-X.Z. and G.W. analyzed the data; S.W. contributed reagents/materials/analysis tools; G.W. wrote the paper. All authors have read the final version of the manuscript.

Conflicts of Interest: The authors declare no conflict of interest.

\section{References}

1. Iwasaki, T.; Horikawa, H.; Matsumoto, K.; Miyoshi, M. An electrochemical synthesis of 2-acetoxy-2-amino acid and 3-acetoxy-3-amino acid derivatives. J. Org. Chem. 1977, 42, 2419-2423. [CrossRef] [PubMed]

2. Olsen, R.K.; Kolar, A.J. $N$-acylimines as intermediates in reactions of $\alpha$-substituted $\alpha$-amino acids and dehyroamino acids. Tetrahedron Lett. 1975, 16, 3579-3582. [CrossRef]

3. Williams, R.M. Synthesis of Optically Active $\alpha$-Amino Acids; Pergamon Press: Oxford, UK, 1993.

4. Ben-Ishai, D.; Moshenberg, R.; Altman, J. A new synthesis of amino acids-II: Amidoalkylation of olefins with glyoxylic acid derivatives. Tetrahedron 1977, 33, 1533-1542. [CrossRef] 
5. Apitz, G.; Jäger, M.; Jaroch, S.; Kratzel, M.; Schäffeler, L.; Steglich, W. Generation of $\alpha$-acetoxyglycine residues within peptide chains: a new strategy for the modification of oligopeptides. Tetrahedron 1993, 49, 8223-8232. [CrossRef]

6. Weinstein, B.; Lande, S. Peptides: Chemistry and Biochemistry; Marcel Dekker, Inc.: New York, NY, USA, 1970.

7. Apitz, G.; Steglich, W. Conversion of serine and threonine residues into $\alpha$-acyloxy-, a-alkylthio-, and $\alpha$-halogenoglycine moieties: A new strategy for the modification of peptides. Tetrahedron Lett. 1991, 32, 3163-3166. [CrossRef]

8. Ishikawa, N.; Mustafa, E.S.; Takaoka, A. Trifluoropyruvic Acid Hydrate in Heterocyclic Cynthesis Part III: A Novel Synthesis of 4-(Trifluoromethyl)-oxazolones and other Related Compounds. Heterocycles 1986, 24, 1541-1547. [CrossRef]

9. Morin, R.B.; Gordon, E.M. Formation of dehydropeptides by oxidation of peptide oxazolones. Tetrahedron Lett. 1973, 14, 2163-2166. [CrossRef]

10. Murahash, S.I.; Saito, T.; Naota, T.; Kumobayashi, H.; Akutagawa, S. Ruthenium-catalyzed oxidation of $\beta$-lactams with molecular oxygen and aldehydes. Tetrahedron Lett. 1991, 32, 5991-5994. [CrossRef]

11. Horikawa, H.; Iwasaki, T.; Matsumoto, K.; Miyoshi, M. A new synthesis of 2-alkoxy-and 2-acetoxy-2-amino acids by anodic oxidation. Tetrahedron Lett. 1976, 17, 191-194. [CrossRef]

12. Pouységu, L.; Deffieux, D.; Quideau, S. Hypervalent iodine-mediated phenol dearomatization in natural product synthesis. Tetrahedron 2010, 66, 2235-2261. [CrossRef]

13. Tian, T.; Zhong, W.-H.; Meng, S.; Meng, X.-B.; Li, Z.-J. Hypervalent Iodine Mediated para-Selective Fluorination of Anilides. J. Org. Chem. 2013, 78, 728-732. [CrossRef] [PubMed]

14. Samanta, R.; Matcha, K.; Antonchick, A.P. Metal-Free Oxidative Carbon-Heteroatom Bond Formation Through C-H Bond Functionalization. Eur. J. Org. Chem. 2013, 26, 5769-5804. [CrossRef]

15. Moreno, I.; Tellitu, I.; Herrero, M.; SanMartin, R.; Dominguez, E. New perspectives for iodine (III) reagents in (hetero) biaryl coupling reactions. Curr. Org. Chem. 2002, 6, 1433-1452. [CrossRef]

16. Kitamura, T.; Kuriki, S.; Morshed, M.H.; Hori, Y. A practical and convenient fluorination of 1, 3-dicarbonyl compounds using aqueous hf in the presence of iodosylbenzene. Org. Lett. 2011, 13, 2392-2394. [CrossRef] [PubMed]

17. Saito, M.; Miyamoto, K.; Ochiai, M. Hypervalent phenyl- $\lambda$ 3-iodane-mediated para-selective aromatic fluorination of 3-phenylpropyl ethers. Chem. Commun. 2011, 47, 3410-3412. [CrossRef] [PubMed]

18. Sharma, D.; Ranjan, P.; Prakash, O. Facile Iodine (III)-Mediated Approach for the Regioselective Chlorination of 2-Aryl-2,3-dihydro-4(1H)-quinolones. Synth. Commun. 2009, 39, 596-603. [CrossRef]

19. Wardrop, D.J.; Bowen, E.G.; Forslund, R.E.; Sussman, A.D.; Weerasekera, S.L. Intramolecular oxamidation of unsaturated O-alkyl hydroxamates: A remarkably versatile entry to hydroxy lactams. J. Am. Chem. Soc. 2009, 132, 1188-1189. [CrossRef] [PubMed]

20. Zhao, X.-F.; Zhang, C. Iodobenzene dichloride as a stoichiometric oxidant for the conversion of alcohols into carbonyl compounds; two facile methods for its preparation. Synthesis 2007, 4, 551-557. [CrossRef]

21. Zhong, W.-H.; Yang, J.; Meng, X.-B.; Li, Z.-J. BF 3 -OEt 2 -Promoted Diastereoselective Diacetoxylation of Alkenes by PhI(OAc) $)_{2}$. J. Org. Chem. 2011, 76, 9997-10004. [CrossRef] [PubMed]

22. He, G.; Zhao, Y.; Zhang, S.; Lu, C.; Chen, G. Highly efficient syntheses of azetidines, pyrrolidines, and indolines via palladium catalyzed intramolecular amination of $\mathrm{C}\left(\mathrm{sp}^{3}\right)-\mathrm{H}$ and $\mathrm{C}\left(\mathrm{sp}^{2}\right)-\mathrm{H}$ bonds at $\gamma$ and $\delta$ positions. J. Am. Chem. Soc. 2011, 134, 3-6. [CrossRef] [PubMed]

23. Boto, A.; Gallardo, J.A.; Hernández, D.; Hernández, R. Synthesis of unnatural amino acids from serine derivatives by $\beta$-fragmentation of primary alkoxyl radicals. J. Org. Chem. 2007, 72, 7260-7269. [CrossRef] [PubMed]

24. Watson, T.J.; Horgan, S.W.; Shah, R.S.; Farr, R.A.; Schnettler, R.A.; Nevill, C.R.; Weiberth, F.J.; Huber, E.W.; Baron, B.M.; Webster, M.E. ChemInform abstract: Chemical development of MDL 103371: An N-methyl-D-aspartate-Type glycine receptor antagonist for the treatment of stroke. Org. Process. Res. Dev. 2000, 4, 477-487. [CrossRef]

25. Stead, D.; Carbone, G.; O’Brien, P.; Campos, K.R.; Coldham, I.; Sanderson, A. Asymmetric deprotonation of $N$-boc piperidine: React IR monitoring and mechanistic aspects. J. Am. Chem. Soc. 2010, 132, 7260-7261. [CrossRef] [PubMed]

26. Eisenbeis, S.A.; Chen, R.; Kang, M.; Barrila, M.; Buzon, R. Utilization of ReactIR in fit for purpose process enablement. Org. Process. Res. Dev. 2014, 19, 244-248. [CrossRef] 
27. Mizukami, F.; Ando, M.; Tanaka, T.; Imamura, J. The acetoxylation of p-substituted acetophenones and $\beta$-diketones with (diacetoxyiodo) benzene. Bull. Chem. Soc. Jpn. 1978, 51, 335-336. [CrossRef]

28. Padwa, A.; Akiba, M.; Cohen, L.A.; Macdonald, J.G. Aza cope rearrangements in the cyclopropenyl- and allyl-substituted. DELTA. 2-oxazolinone systems. J. Org. Chem. 1983, 48, 695-703. [CrossRef]

(C) 2017 by the authors. Licensee MDPI, Basel, Switzerland. This article is an open access article distributed under the terms and conditions of the Creative Commons Attribution (CC BY) license (http://creativecommons.org/licenses/by/4.0/). 